\title{
BANGSA MONGOL MENDIRIKAN KERAJAAN DINASTI ILKHAN BERBASIS ISLAM PASCA KEHANCURAN BAGHDAD TAHUN 1258-1347 M
}

\author{
Suryanti
}

\begin{abstract}
The purpose of this research was to find out how the circumstantial of the Ilkhan Dynasty under Mongol leadership and the leadership of the Ilkhan dynasty and its relationship with the Islamic Society, so that the Mongols who initially hated the Muslims had established the Islamic empire under the rule of the Ilkhan dynasty.

This study discusses about the Mongols established the empire of Islam-based Ilkhan Dynasty after the destruction of Baghdad Year 1258-1347 M. the main problem in this research is how the background of the Ilkhan Dynasty that eventually became one of the Islamic Kingdom and how the leadership figure of Ilkhan dynasty and its relationship with the Muslim community in Persia. Gazana Khan was one of the important figures in the Ilkhan Dynasty government. Gazana Khan as a descendant of Genghis Khan has made a transformation for the Mongols through the Ilkhan Dynasty during the reign of the Ilkhan Dynasty recognized Islam as the official religion of the government and built civilization based on the spirit of Islam.

The results display that in the journey of the Mongols under the leadership of Jengis Khan and Huagu Khan had an important role in destroying Islamic rule in Baghdad. The expansion of the Mongols into Baghdad caused the destruction of the Abbasid Dynasty as the center of Islamic civilization. After the destruction of Baghdad, this nation again built Islamic civilization under the rule of Ilkhan Dynasty.
\end{abstract}

Keywords: Dynasty, Destruction of Baghdad, Islamic Civilization

\section{A. Pendahuluan}

Dinasti Ilkhan merupakan salah satu cabang rumpung dari bangsa Mongol, Bangsa Mongol yang berada di daratan Asia Timur, berbatasan dengan Rusia di sebelah utara dan Republik Rakyat Cina di Selatan, mempunyai nilai keutamaan yang berbeda dibanding dengan bangsa-bangsa yang lain, mulai dari kontraversi lahirnya bangsa Mongol hingga pada gaya kepemimpinan Jengis Khan dan Hulagu Khan yang dikenal sebagai sosok legendaries penakluk beberapa Negara. ${ }^{1}$

Pada abad ke-7 M Sentral Asia (Asia Tengah) dihuni oleh suku-suku yang liar lagi biadab dari pegunungan Altai. Di sebelah Barat, mereka diklasifikasikan sebagai orang-orang Turki. Sedangkan di sebelah Timur diklasifikasikan sebagai orang-orang Mongol. Orangorang Turki setelah berpindah dan memasuki daerah kerajaan Islam di bahgian Barat dan memeluk agama Islam, menjadi suku yang berbudaya. Pada tahun1206 M, Suatu suku kecil dari bangsa Mongol berkumpul di Laut Baikal.

Tahun 1207-1215 M merupakan pergerakan Jengis Khan dalam melakukan perluasan wilayah. Kejeniusan Jengis Khan dan keberanian orang-orang yang loyal padanya menjadikan dominasi kekuasaannya meluas secara cepat keseluru Mongolia dan daerah-daerah

\footnotetext{
${ }^{1}$ Najamuddin Muhammad, Jengis Khan:Sang Pengembala yang Menaklukan Dunia (Cet. I; Jokjakarta: Buku Biru, 2010), h. 20.
} 
tetangganya, sehingga daerah kekuasaannya terlihat diperbatasan Iran, Khawarizn di Asia Tengah, yang luasnya meliputi Persia hingga Transoxiana. Karena kekagumannya akan kekuatan militer (khususnya senjata) dan majunya kebudayaan bangsa Iran yang pada saat itu berdirinya Dinasti Abbasiyah di Baghdad, maka Jengis Khan mengirim pada duta dalam berdagang. Disinilah awal sejarah hubungan bangsa Mongol dengan ummat Islam hingga berakhir pada kehancuran kerajaan-kerajaan Islam. ${ }^{2}$

Pasukan Mongol dibawa pimpinan Jengis Khan dan Hulagu Khan, meluluh lantahkan Transoxania dan Khurasan (1219-1231) kemudian menumbangkan kekuasaan Saljuk Rum (1235-1236 M) Bahgdad hancur lebur dan Khalifah Abbasiyah dibunuh (1258 M). Pasukan kencana kumpulan dari beberapa suku Mongol menyapu wilayah Kota-kota, budaya, perdagangan, ilmu agama dan filsafat selama setenga abad di bantai dan di hancurkan dengan tingkat kehancuran yang belum pernah terjadi sebelumnnya. ${ }^{3}$ Bangsa mongol berhasil menguasai Baghdad pada tahun $1258 \mathrm{M}$ yang menandakan kehancuran bagi peradaban Islam. $^{4}$

Penelitian ini merupakan penelitian pustaka dengan menggunakan metode penelitian sejarah atau historical method. Penelitian dengan menggunakan metode sejarah merupakan sebuah penyelidikan atau kajian yang kritis terhadap keadaan-keadaan, perkembangan serta pengalaman di masa lampau dan menimbang secara cukup teliti dan hati-hati tentang bukti validitas dari sumber-sumber sejarah serta interpretasi dari sumber-sumber keterangan yang ada.

Tulisan ini akan mendeskripsikan Hulagu Khan mendirikan kerajaan dinasti Ilkhan yang menjadi salah satu kerjaan Islam dari keturunan bangsa Mongol serta kepemimpinan dinasti Ilkhan dan hubungan masyarakat Islam pasca kehancuran Baghdad tahun 1258-1347 M.

\section{B. Latar Belakang Berdirinya Dinasti Ilkhan}

Hulagu Khan dikenal dengan sebutan Hülegü, Hulegu and Halaku. adalah Khan pertama dari dinasti Khan yang menguasai wilayah Persia, Kehancuran kota Bgahdad yang merupakan pusat kebudayaan dan ilmu pengetahuan Islam telah dihancurkan oleh Hulagu Khan pada tahun 1258 M. melakukan peperangan dan pembantaian besar-besaran terhadap penduduk yang ada di daerah Perisa. Ada beberapa faktor yang menjadikan Hulagu Khan berkeinginan menguasai wilayah Islam diantaranya : Ibu Hulagu, istri dan sahabat dekatnya, Kitbuq aadalah seorang Kristen fanatik yang memendam kebencian mendalam terhadap orang muslim, dan para penasehatnya banyak yang berasal dari Persia yang memang berharap dapat membalas dendam atas kekalahan mereka satu abad sebelumnya ketika Persia ditaklukan oleh pasukan muslim pada masa Khalifah Umar bin Khattab. ${ }^{5}$

Keberhasilan ekspansi yang dilakukan oleh Hulagu Khan terutama kehancuran Baghdad tahun $1258 \mathrm{M}$, telah mendirikan suatu kerajaan Mongol dengan gelar Ilkhan. Dinasti Ilkhan berdiri pada tahun 1259, pada saat Hulagu Khan berhasil memantapkan kekuasaannya

\footnotetext{
${ }^{2}$ Abdul Karim, Islam di Asia Tengah; Sejarah Dinasti Mongol - Islam, h. 35-36.

${ }^{3}$ Antoni Black, pemikiran politik Islam (cet. I; Jakarta: PT Serambi Ilmu Semesta, 2006), h. 259.

${ }^{4}$ Ira M. Mapidus, Sejarah Sosial Ummat Islam, ter. Ghufron A. mas'adi (Cet. II; Jakarta: PT Raja Grafindo Persada, 2000), h. 639.

${ }^{5}$ HulaguKhan, Wikipedia.http://id.wikipedia.org/w/index.php?title=Hulagu_Khan\&oldid (13 Agustus 2012).
} 
di Baghdad. Ilkhan dalam bahasa Mongol adalah kepala suku, dalam makna khusus dikalangan Mongol juga disebut sebagai perwakilan dari pusat kekuasaan Khan Agung, yang memiliki wilaayah yang sangat luas. Ilkhan merupakan gelar yang diberikan kepada Hulaghu Khan sebagai bentuk penghargaan terhadap prestasi-prestasinya yang diperolehnya ketika sukses melakukan ekspansi wilayah dan mengalahkan setiap musuh-musuhnya. Dinasti Ilkhan yang didirikan oleh Hulagu Khan memliki kekuasaan meliputi dari lembah sungai Amu Daria sampai Syam dan dari Kawkasus sampai Hidukush. ${ }^{6}$ Kehadiran dinasti Ilkhan yang menegakkan ajaran Islam sebagai agama resmi kenegaraan, merupakan terobosan baru bagi peradaban Islam di tangan bangsa Mongol.

Baghdad dan daerah-daerah yang ditaklukkan Hulagu Khan telah diperintah oleh Dinasti Ilkhan, Ummat Islam yang masi menetap di daerah Baghdad telah dipimpin oleh Hulagu Khan seorang raja yang beragama Syamanisme. Hulagu Khan sangat membenci Ummat Islam, kebencian itupu menjadi-jadi dikarenakan istrinya merupakan seorang Kristen yang mendorong untuk melakukan pembantaian terhadap kaum Muslimin. Akan tetapi di akhir-akhir kehidupan Hulagu Khan telah mempercayakan pendidikan putra keduannya, Teguder kepada seorang pendidik Mualim. Hulagu khan Mneinggal pada tahun 663 H/1265 M. ${ }^{7}$ Kebencian Hulagu Khan terhadap Ummat Islam dikarenakan adanya dukungan dari Istrinya yang beragama kristen.

Keberhasilan Hulagu Khan menguasai Persia dan Irak, tidak menutup kemungkinan untuk melakukan ekspansi di berbagai negara lain, Hulagu bergerak untuk memerangi Syiria dan daerah-daerah lain yang berada di bawah kekuasaan Dinasti Mamluk. Hulagu sangat tertarik menguasai Mesir, akan tetapi pasukan Mamluk lebih kuat dan lebih cerdik. ${ }^{8}$ Pada tahun 1260 M pasukan Mongol berhasil menduduki Nablus dan Gaza. Panglima tentara Mongol, Kitbugha, mengirim utusan ke Mesir meminta supaya Sultan Qutuz penguasa dinasti Mamluk menyerahkan diri. Permintaan tersebut ditolak utuzan bangsa Mongol telah dibunuh oleh penguasa Dinasti Mamluk, Tindakan Qutuz ini menimbulkan kemarahan dikalangan tentara Mongol. Kitbugha kemudian melintasi Yordania menuju Galilie Pasukan ini bertemu dengan pasukan Mamalik yang dipimpin langsung oleh Qutuz dan Baybras di 'Ain Jalut. Pertempuran dasyat terjadi, pasukan Mamaluk berhasil menghancurkan tentara Mongol, 3 September 1260 M. $^{9}$

Mamluk memiliki keuntungan pengetahuan tentang medan perang. Taktik yang dipakai oleh panglima Baibars adalah dengan memancing keluar pasukan berkuda Mongol yang terkenal hebat sekaligus kejam ke arah lembah sempit sehingga terjebak, kemudian pasukan kuda mereka melakukan serangan balik dengan kekuatan penuh yang sebelumnya memang sudah bersembunyi di dekat lembah tersebut. Taktik ini menuai sukses besar. Pihak Mongol terpaksa mundur dalam kekacauan bahkan panglima perang mereka, Kitbuqa berhasil ditawan dan akhirnya dihukum mati. ${ }^{10}$

\footnotetext{
${ }^{6}$ Abdul Karim, Islam di Asia Tengah, h. 79.

${ }^{7}$ Tim Riset dan Studi Islam Mesir: Ensiklopedi Sejarah Islam Imperium Mongol Muslim, Negara Utsmani, Muslim Asia Tenggara, Muslim Afrika (Cet. I; Jakarta: Al-Kautsar, 2013), h. 50

${ }^{8}$ Hasan Ibrahim Hassan, Sejarah Dan Kebudayaan Islam (Cet. I; Yokyakarta, Kota Kembang, 1989), h. 151

${ }^{9}$ Ahmad Syalabi, Mausu'ah al-Tarikh al-Islami wa al-Hadharah al-Islamiyah, (Cet. VII; Kairo: Maktabah al-Nahdhah al-Mishriyah, 1979), h. 746

${ }^{10}$ David Morgan, The Mongols, Cambridge : Black Well, 1990, h. 89
} 
Keruntuhan kota Baghdad sampai ke Negara-negara Islam yang lain, rasa kesedihan menyelimuti mereka semua. Meskipun khalifa Abbasiyah sudah tidak lagi memiliki kekuasaan secara menyeluruh kepada Negara-negara tersebut tetapi ummat Islam masih tetap menjadi symbol bagi agama Islam. dia masih memiliki kedudukan maknawi yang kuat didalam jiwa seluruh ummat Islam. ${ }^{11}$

Pada kenyataannya kejadian seperti ini merupakan ujian yang belum pernah menimpah dunia Islam. Meskipun musuh-musuh Islam berusaha untuk memadamkan cahaya kebenaran niscaya mereka tidak mampu untuk melakukannya. Allah telah berjanji akan menjaga agama-Nya. Allah berfirman (Qs. As-Saffat/37: 8-9) :

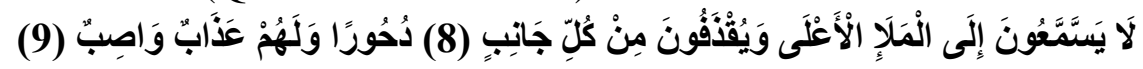

Terjemahan:

Syaitan-syaitan itu tidak dapat mendengar-dengarkan (pembicaraan) Para Malaikat dan mereka dilempari dari segala penjuru. untuk mengusir mereka dan bagi mereka siksaan yang kekal. ${ }^{12}$

Kehadiran dinasti Mamluk yang merupakan Dinasti dengan pemimpin dari Golongan para budak ini mampu membendung topan penyerangan bangsa Mongol. Pada saat dunia Islam tidak ada lagi yang tersisa kecuali satu Negara besar yang dapat menghadapi bahaya Mongolia ini. Negara itu adalah Negara Mesir kerajaan Dinasti Mamluk.

\section{A. Kepemimpinan Dinasti Ilkhan dan Hubungan Masyarakat Islam}

Jengis Khan menganugrahkan kekuasan kepada Tolui putranya atas Negri Persia dan Khurasan beserta seluruh Negri Arab dan Asia kecil yang bisa dicakupnya. Dinasti Tolui merupakan Dinasti yang paling luas wilayah kekuasaanya. Sosok Hulagu yang merupakan putra dari Tolui telah mengambil alih kekuasaan wilayah-wilayah tersebut. Pemerintahan Hulagu Khan yang dikenal sebagai Dinasti Ilkhan. ${ }^{13}$

Hancurnya kota Baghdad pada tahun 1258 M ke tangan bangsa Mongol bukan saja mengakhiri Khalifah Abbasiyah akan tetapi juga merupakan awal dari masa kemunduran politik dan peradaban Islam, karena Bagdad sebagai pusat kebudayaan dan peradaban Islam yang sangat kaya khazanah ilmu pengetahuan itu ikut pula dibumihanguskan oleh pasukan Mongol yang dipimpin Hulagu Khan. Hulagu Khan merupakan pendiri pertama Dinasti Ilkhan pasca kehancuran Bahgdad. Hulagu Khan telah memilihki peranan uatama dalam melanjutkan citra buruk Bangsa Mongol di mata kaum Muslimin. Berbagai ekspansi dan kejahatan penaklukkan yang dilakukan pada masa pemerintahan Dinasti Abbasiyah di Baghdad. Akan tetapi satu hal yang menarik dalam diri Hulagu Khan, Dia adalah seorang pecinta Ilmu pengetahuan dan pendidikan serta kegiatan ilmiah. Hulagu Khan sangat tertarik dengan bentuk bangunan atau arsitektur, mengabdikan diri kepada studi ilmu pengetahuan dan mengadakan percobaan (eksperimen-eksperimen) pada tahun 1259 Ahli angkasa luar yang bernama Nazir al-Din (1201-1274) seorang sejarawan terkemuka ahli matematika, astronomi, yang lahir di Tush dekat kota Mezhhad Iran, atas dorongan ahli astrologi dan

\footnotetext{
${ }^{11}$ Muhammad Mahdu Al-qadhi, 10 Pahlawan Penyebar Islam (cet. I; Yokyakarta: Mitra pustaka,2003), h. 397.

${ }^{12}$ Departemen Agama, Al-Quran dan terjemahnya (Jakarta: Darus Sunnah, Ed. 2002), h. 446.

${ }^{13}$ Hasan Ibrahim Hasan, Tarik Al-Islam, Jilid IV, (Kairo, Maktabah An-Nahdah Al-Misriyah, 1979), h. 134.
} 
filsafat Hulagu Khan mendirikan sebuah observatrium di Maragha, Ajarbyzan untuk mendeteksi angkasa luar yang bertahan di sana smapai beberapa abad. ${ }^{14}$

Dengan melihat keteranga tersebut diatas bahwa pemerintahan Dinasti Abbasiya merupakan pusat ilmu pengetahuan telah di hancurkan oleh Hulagu Khan, akan tetapi setelah Hulagu Khan mengambil alih keuasaan tempat tersebut telah dijadikan tempat bagi para ahli teologi Islam, hal ini ditunjukkan kecintaan Hulagu Khan terhadap ilmu pengetahuan. Berkaitan hal tersebut penulis dapat menyimpulkan bahwa kebencian Hulagu Khan terhadap Ummat Islam Itu memang disebabkan karna sifat serta kehidupan masyarakatnya Mongol yang keras nomaden serta salah satunya adalah balasan dendam terhadap Ummat Islam atas perlakuan dan penghinaan yang diberikan oleh Raja Kawarizm kepada bangsa Mongol, sehingga berkeinginan menjadi penguasa melebihi dari kekuasaan Ummat Islam. disis lain Hulagu Khan ini memiliki seorang istri serta sahabat yang beragama Kristen yang menghasut Hulagu Khan untuk menghancurkan Ummat Islam.

Kondisi kehidupan keberagaman pada masa Hulagu Khan sangatlah toleran, akan tetapi kemajuan Islam di antara bangsa Mongol sangatlah lamban dibanding agama Kristen dan Budha. Demi memperkuat posisinya terhadap kemungkinan serangan dari Barkhe Kahn dan sultan Mesir Mamluk, Hulagu menjalin hubungan dengan kaum Kristen menerima persekutuan Kristen Timur dengan Raja Armenia serta pasukan Salib dari Konstantinopel. Hulagu Khan sangat simpati dan membantu orang-orang Kristen hal ini dikarenakan adanya dukungan dari sang istri yang beragama Kristen. ${ }^{15}$ Demi memperkuat pertahanan Hulagu khan menjalin hubungan baik dengan kaum kristen yang telah mempunyai kemampun untuk melindungunya dari serangan luar, selain itu hubungan Hulagu Khan dengan kaum Kristen disebabkan oleh hasutan istrinya yang telah beragama Kristen.

Dinasti Ilkhan memerintah di wilayah yang memanjang dari Asia Kecil di Barat dan India di Timur dengan ibukotanya Tabriz. Di wilayah itu sekarang membentang negara Turki, Syiria, Irak, Iran, Uzbekistan dan Afghanistan. Selama dinasti ini berkuasa, terdapat 16 raja yang pernah berkuasa. Di antara raja-raja tersebut yang pertama adalah Hulaghu Khan, seorang raja Mongol dari Dinasti Ilkhan yang merupakan anak dari Tuli Khan. Ia merupakan cucu dari Jangis Khan beragama Syamanism. ${ }^{16}$ Masa kekuasaan dari Hulagu Khan hanya berlangsung selama tujuh tahun karena pada tahun 1265 Ia meninggal dunia dan dimakamkan di Pulau Kaboudi yang terletak di dalam Danau Urmia. Dia digantikan oleh anaknya, Abaqa yang tetap meneruskan peperangan dengan Berke ${ }^{17}$ hulagu Khan sampai pada pemerintahan Abu zaid Dinasti Ilkhan telah mulai mengalami perpecahan kemunduran. pasca pemerintahan Abu Said Dinasti Ilkhan diperintah Raja Arpha, Musa, Muhammad, Jahan Timur, Sati Bek dan Sulaeman. Mereka semua adalah figur raja-raja yang lemah, karena wilayah kerajaan Dinasti Ilkhan banyak terjadi perpecahan dan pertikaian, sehingga wilayah kekuasaannya digantikan oleh dinasti-dinasti lokal. Adapun sililah kepeimpinan Dinasti Ilkhan sebagai berikut $:^{18}$

\footnotetext{
${ }^{14}$ Tim Riset dan Studi Islam Mesir: Ensiklopedi Sejarah Islam Imperium Mongol Muslim, Negara Utsmani, Muslim Asia Tenggara, Muslim Afrika, h. 49

${ }^{15}$ Abdul karim, Pemikiran Dan Peradaban Islam, h. 304

${ }^{16}$ Hasan Ibrahim Hasan, Sejarah Dan Kebudayaan Islam, h. 307.

${ }^{17}$ Anmol Publication pvt. Ltd, Internasional Encyclopaedia of Islamic Dynasties (Cet.I; Delhi: Mehra Offset Press, 2000), h. 469.

${ }^{18}$ Joesoef Sou'yb, Sejarah Daulat Abbasiyah, Jilid III (Cet. I; Jakarta: Bulan Bintang, 1978), h. 324.
} 


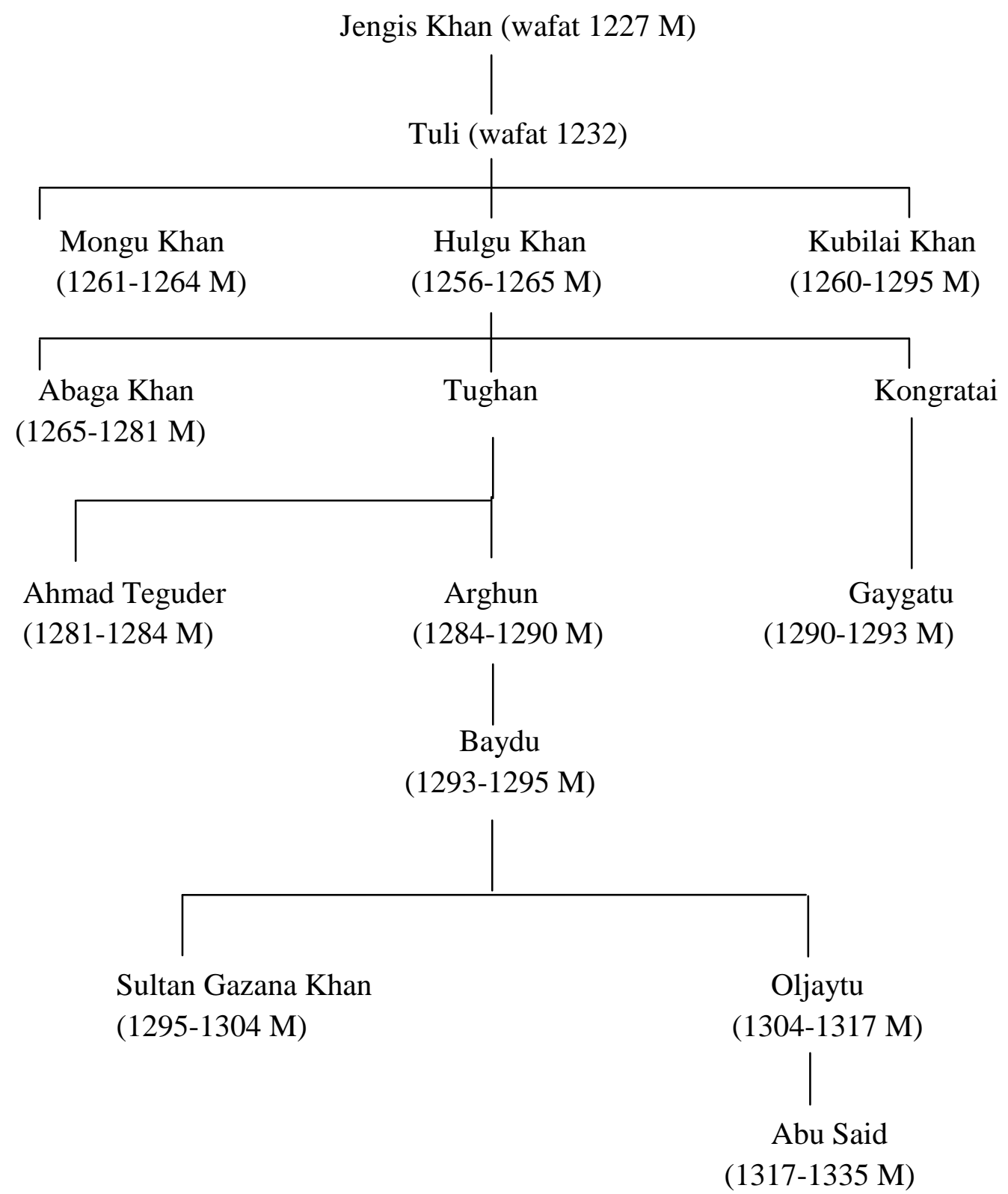

Kepemimpinan Hulagu Khan digantikan oleh anaknya yang bernama Abaga Khan. Ia merupakan salah satu di antara penguasa Dinasti Ilkhan yang memerintah paling lama, yaitu selama 17 tahun. Ia memerintah dari tahun 1265-1281 M. Berbeda dengan bapaknya yang beragama Syamanism, maka Abaga Khan adalah seorang pemeluk agama Kristen Nestorian. ${ }^{19}$ Abaga Khan mengkonsolidasikan pemerintahanya dengan penuh semangat dan memperhatikan kondisi negara dengan baik. Pada masa pemerintahan Abaga Khan melakukan kerja sama dengan golongan kaum Kristen, mengirimkan duta-duta kebeberapa pangeran di Eropa - Louis Prancis, Raja Charles Sicilia dan Raja James Aragon untuk meminta persekutuan mereka melawan Muslim. Kebencian Abaga Kahn terhadap Islam dikerenakan adanya Hubung dengan kaum Salibis Kristen, yaitu pernikahanya dengan putri

\footnotetext{
${ }^{19}$ Hasan Ibrahim Hasan, Sejarah dan Kebudayaan Islam, h. 306
} 
Kaisar Konstantinovel (Byzantium) yang merupakan taktik kaum salibis untuk menghancurkan Islam. ${ }^{20}$

Masa pemerintahan Abaga Khan melakukan peperangan terhadap keturunannya termasuk keponakanya sendiri yang telah menguasai wilayah Mongol Utara, peperangan dengan Berke Khan, kemudian dengan Mongkay Khan di Timur Abaga Khan memperoleh kemenangan besar tehadap Mongkay di Timur, selanjutnya peperangan di bagian Brat antara Dinasti Mamluk yang mampu mencapai Anatolia, pada tahun 679 H. Abaga Khan berusaha merebut Negri Syam akan tetapi dikalahkan oleh Sultan Qalawun pada tahun 680 H. Sehingga Sungai Eufrat telah menjadi perbatasan antara Dinast Ilkhan dengan Dinasti Mamluk. ${ }^{21}$ Pada masa pemerintahan Abaga Khan terpokus melakukan penyerangan di daerah Mongol Utara dan penyerangan terhadap Ummat Islam atas kehadiran Dinasti Mamluk di Mesir, kekalahan Bngasa Mongol merebut kekuasaan negri Syam menjadikan daera Sungai Eufrat telah menjadi perbatasan antara Dinast Ilkhan dengan Dinasti Mamluk.

Abaga Khan meninggal pada tahun $680 \mathrm{H}$. Tahtanya pun diwariskan kepada Tegudhar saudaranya sendiri. Penguasa ketiga dari dinasti ini adalah Ahmad Teguder. Ia memerintah dari tahun 1282-1284 M. Ahmad Teguder dibesarkan sebagai seorang Kristen yang suda dibabtis dan dijuluki dengan nama Nicola. Ketika Ahmad teguder mencapai dewasa telah memeluk Islam sebagai akibat dari pergaulan teman-teman Muslimnya. Pada masa pemerintahan Teguder Ummat Islam sedikit lebih membaik, sehingga jabata-jabatan penting dipemerintahan telah dipercayakan oleh sebagian yang beragama Islam. ${ }^{22}$ Ahmad Teguder adalah raja Dinasti Ilkhan pertama yang memeluk Islam atas dasar hubungn dan didikan dari seorang Muslim sehingga berkeinginan membelah dan melindungi Ummat Islam.

Ahmad Teguder berkeinginan mengislamkan seluruh bangsa Mongol dan membawah mereka kepada ajaran Nabi Muhammad saw. Akan tetapi banyak diantara masyarakat Mongol memberikan penolakan tidak ingin meninggalkan agama yang sudah dianutnya, Ahmad Teguder tidak berani mengajak masyarakat Mongol masuk Islam, Ahmad Teguder mengupayakan dengan cara memberikan hadiah, anugerah, pangkat, dan kehormatan, sehingga sejumlah besar orang Mongol masuk Islam pada eranya. ${ }^{23}$ Pada masa kepemimpinan Ahmad Teguder mengupayakan keturunannya masuk ajaran Islam akan tetapi hanya sebagian kecil yang ikut kepada Ahmad Teguder, masyarakat Muslim pada masa kepemimpinanya telah memperoleh kebijakan yang baik serta memposisikannya pada jabatan pemerintahan.

Ahamad Teguder mengirimkan surat kepada para Sultan di Mesir guna memberitahukan bahwa Dia telah memeluk Islam, berkeinginan melindungi dan membantu perkembangan Islam hidup dalam kedamaian dan persahabatan dengan semua Ummat Islam. Berupaya mengikat peranjian perdamaian dengan Sultan Qalaun di Mesir (Dinasti Mamluk) serta mengirim para duta ke Mesir untuk melakukan kerja sama. Akan tetapi keinginan Ahmad Teguder tidak berlangsung lama karena munculnya konspirasi hebat dari kalangan Mongol yang terkemuka untuk menurunkan Ahmad Teguder dari tahtanya yang telah beralih memeluk Agama Islam. Sehingga Ahmad Teguder dibunuh oleh Argun, yang kemudian

\footnotetext{
${ }^{20}$ Abdul Karim, Islam di Asia Tengah; Sejarah Dinasti Mongol - Islam, h. 82.

${ }^{21}$ Tim Riset dan Studi Islam Mesir: Ensiklopedi Sejarah Islam Imperium Mongol Muslim, Negara Utsmani, Muslim Asia Tenggara, Muslim Afrika, h. 51

${ }^{22}$ Samsul Munir, Sejarah Peradaban Islam, (Cet.II; Jakarta : Amzan, 2010), h. 220

${ }^{23}$ Tim Riset dan Studi Islam Mesir: Ensiklopedi Sejarah Islam Imperium Mongol Muslim, Negara Utsmani, Muslim Asia Tenggara, Muslim Afrika, h. 10.
} 
menggantikannnya menjadi raja Dinasti Ilkhan (1284-1291). Raja yang keempat ini adalah penganut agama Kristen Nestorian militan, yang karena kefanatikannnya banyak melakukan tindakan refresif dengan mengusir dan membunuh orang-orang Islam. ${ }^{24}$ Ahmad Teguder adalah pemimpin Dinati Ilkhan yang pertema memeluk Islam, Atas dasar dorongan yang telah tumbuh dalam naungan Ummat Islam telah berkeinginan meperbaiki peradaban Islam yang telah dimusnahkan oleh ayahnya. Akan tetapi pemerintahannya hanya mencapai dua tahun lamanya sehingga perubahan yang dicapanya tidak begitu terlihat.

Arghun Khan dalam kepemimpinannya telah mewariskan kebencian terhadap Islam dari Abaqa Khan ayahnya sendiri. Arghu Khan melakukan penindasan terhadap kaum Muslimin di negri-negrinya dan memecat seluruh pejabat Muslim yang terkait dalam peradilan dan ekonomi. ketika Argu Khan mengetahui pamanya telah memeluk Islam, Argu Khan berusaha menyingkirkan Ahmad Teguder dan membunuhnya. Arghun Khan telah melakukan persekutuan dengan pasukn Salib dan bangsa Armenia untuk melawan Dinasti Mamluk serta kerajaan Mongol yang telah memeluk Islam. ${ }^{25}$

Argahun Khan meninggal pada tahun $691 \mathrm{H}$. Tahtanyapun diwariskan kepada saudaranya Gaygathu. Ia memerintah selama empat tahun, dari tahun 1291 sampai dengan 1295 M. Ia kemudian digantikan oleh Baydu yang memerintah tidak lama, kurang lebih dari setahun, yakni masih dalam tahun 1295. Dari masa Hulagu Khan sampai Baydu, kecuali Ahmad Teguder, seluruh penguasa Dinasti Ilkhan adalah non-Muslim. Dengan demikian umat Islam yang ada di kawasan tersebut diperintah dan dikuasai oleh penguasa-penguasa Dinasti Ilkhan yang non-Muslim. ${ }^{26}$ pada periode ini tidak ada sebuah perkembangan yang berarti bagi masyarakat Muslim terutama yang menyangkut perkembangan Islam dan peradabannnya, karena memang penguasa-penguasa dari dinasti Ilkhan pada periode ini adalah orang-orang yang tidak memiliki perhatian terhadap Islam. Terutama pada masa pemerintahan Gaykhatu dan Baydu yang waktunya cukup singkat tidak melakukan perubahan dan perbaikan apapun hanya meneruskan bentuk pemerintahan sebelumnya. Pada masa kepemimpinan Gaykhatu dan Baydu termasuk pemimpi Mongol yang lemah dalam pemerintahanya.

Gazana Khan dinobatkan sebagai penguasa Dinasti Ilkhan pada tanggal 3 November 1295 M. merupakan penguasa ke VII Ilkhan, yang pada awalnya telah memeluk agama Budah, masa kecil Gazana Khan banyak dihabiskan ditemani oleh kakenya Abaga yang diberikan pendidikan untuk mempelajari agama Budha. Karena ketajaman akal, intelektualitas, serta berwawasan luas, cepat memahami esensi dan makna Doktrin-doktrin agama Budha. Ketika Gazana Khan berumur 10 tahun dia diangkat menjadi gubernur Khurasan pada masa pemerintahan Ayahnya Arghun Khan. Pendamping dan penasehatnya ialah Amir Nawruz, yang telah memerintah selama 39 tahun di beberapa provinsi Persia di bawah pengawasan langsung Jengis Khan dan penggantinya. Amir Nawruz merupakan pembesar Mongol awal yang memeluk agama Islam secara diam-diam. Atas usaha Amir Nawruz, Ghazan Khan memeluk agama Islam. Ajakan memeluk Islam itu berawal ketika Ghazan sedang berjuang merebut tahta kerajaan dari saingan utamanya, panglima jendral

\footnotetext{
${ }^{24}$ Hasan Ibrahim Hasan, Sejarah dan Kebudayaan Islam, h. 306

${ }^{25}$ Tim Riset dan Studi Islam Mesir: Ensiklopedi Sejarah Islam Imperium Mongol Muslim, Negara Utsmani, Muslim Asia Tenggara, Muslim Afrika, h. 51.

${ }^{26}$ C.E, Bosworth,.diterjemahkan oleh, Ilyas Hasan, Dinasti-Dinasti Islam, (Cet. II; Bandung; Mizan, 1993), h. 176.
} 
Nawruz membantu perjuanganya melawna saudaranya Baydu, Gzana Khan pada saat itu berjanji bahwa jika Ia memenangkan pertempuran dengan Baydu maka Ia akan menerima agama Nabi Muhammad saw. Atas petunjuk dan nasihat Amir Nawruz itulah Ghazan Khan berhasil mengalahkan Baidu dan naik tahta pada tanggal 19 Juni 1295 (4 Sya'ban $644 \mathrm{H}$ ) pada usianya yang ke 24 tahun. Berkata keberhasilan pertempuran yang dilakukanya sehingga Gazana Khan menepati janjinya memeluk Islam $^{27}$

Ghazana Khan sering melakukan diskusi dengan Shekh Sadr al-Din yang merupakan salah seorang penasehat Ghazan yang memeluk Islam. Gazana Khan bertanya sejelas-jelasnya dan sedetail-detailnya mengenai ajaran agama Islam, dan Shekh Sadr al-Din menjelaskan bahwa Islam adalah agama yang sangat kuat dan jelas, terdiri dari semua peraturan dan jalan hidup. Beliau juga menjelaskan tentang kebesaran Allah sebagai tuhan yang Esa dan keutamaan Muhammad sebagai Rasulullah saw. dengan tanda-tanda kerasullannya yang dapat dengan jelas dilihat dan pasti kebenarannya di sepanjang zaman. Janjinya untuk memeluk Islam dipenuhi hari itu juga. Bersama 10.000 orang Mongol lain, termasuk sejumlah pembesar dan jenderal dia mengucapkan dua kalimah syahadat di hadapan Syekh Sadruddin Ibrahim, putra tabib terkemuka al-Hamawi. Setelah empat bulan memerintah, Sultan Ghazan memerintahkan tentaranya menghancurkan kuil Budha, gereja dan sinagor di seluruh kota Tabriz. kemudian dibangun kembali masjid dan madrasah, sebab di tempat yang sama itulah dahulu Hulagu menghancurkan puluhan madrasah dan masjid yang megah. Dengan berbuat demikian dia telah menebus dosa leluhurnya kepada kaum muslimin. Gazana Khan adalah penguasa ke VII yang paling berbakat dari para penguasa Ilkhan sebelumnya, sebagai pengikut dari khan agung memberikan penegasan bahwa ditetaapkanya Islam sebagai agama resmi Negara. ${ }^{28}$ Atas Penjelasan-penjelasan yang diterimanya membuat Ghazana Khan semakin yakin tentang ajaran Islam dan pada tahun itu pula (1295) Ghazan mengakui keesaan Allah dan menambah namanya menjadi Mahmud Ghazan.

Setelah pemimpin Dinasti Ilkhan masuk Islam masyarakat dari kalangan Bangsa Mongol dapat menerima dan masuk agama Islam, dikarenakan mereka berasimilasi dan bergaul dengan masyarakat muslim dalam jangka waktu panjang. Sehingga adanya keinginan tertrik memeluk Islam. Para penguasa dari Dinasti Ilkhan sejak masa kekuasaan Gazana Khan mulai memperhatikan Islam dan kepentingan masyarakat Muslim, serta memposisikan dirinya melalui pembaruan dengan lingkungan masyaraka disekelilingnya, masyarakat Muslim terlebih muslim di Iran telah mendapatkan kemerdekaannya kembali. ${ }^{29}$

Seorang muslim harus dapat berhubungan baik dengan masyarakat yang lebih luas baik dilingkungan pendidikan, kerja, sosial, politik dan lingkungan lainya. Baik orang-orang yang seagama, maupun dengan pemeluk agama lainnya. Hubungan bermasyarakat sudah merupakan fitra manusia. Dalam surat Al-Hujarat dinyatakan bahwa manusia diciptakan dari laki-laki dan perempuan, bersuku-suku dan berbangsa-bangsa agar mereka saling mengenal. Dengan demikian dapat dikatakan bahwa, menurut Alquran, manusia secara fitra adalah mahluk sosial dan hidup bermasyarakat merupakan suatu keniscayaan bagi mereka. ${ }^{30}$ Seperti halnya yang dilakukan oleh keturunan bangsa Mongol yang telah melakukan hubungan

\footnotetext{
${ }^{27}$ Abdul Karim, Islam di Asia Tengah; Sejarah Dinasti Mongol - Islam, h. 85.

${ }^{28}$ Abdul karim, Islam di Asia Tengah; Sejarah Dinasti Mongol-Islam, h. 87.

${ }^{29}$ Hasan, Ibrahin Hasan. Sejarah Dan Kebudayaan Islam, h. 308

${ }^{30}$ Yunahar Ilyas, Kuliah Akhlak (Cet. X; Yokyakarta: pustaka pelajar offset, 2009), h. 205.
} 
bermasyarakat dengan Ummat Muslim sehingga banyak diantara merek telah meninggalkan perilaku buruk yang dilakukan bangsa Mongol sebelumnya dan memeluk Islam. Serta pemimpin dari keturunan bangsa Mongol itu sendiri telah memeluk Islam dan menjadikan Agama Islam sebagai agama resmi negaranya. Semua itu berdasar dari hubungan kemasyarakatan dan berasimilasi dengan golongan ummat Muslim.

Peradaban Islam pada periode pertengahan seringkali dikatakan berada dalam kondisi kemunduran, namun bukan berarti pada periode ini di kalangan masyarakat Muslim tidak ada perhatian sama sekali terhadap upaya-upaya memajukan dan mengembangkan peradaban Islam. Hal ini terjadi pada pemerintahan Dinasti Ilkhan yang pada awal kehadirannnya dikatakan sebagai dinasti pembawa bencana, namun dalam perjalanan sejarah dinasti ini memiliki peran dalam upaya membangun dan mengembangkan peradaban Islam, terutama setelah dinasti ini diperintah oleh raja-rajanya yang memeluk agama Islam. ${ }^{31}$

Pada tahun 1295 M. Ghazana Khan diangkat sebagai raja yang ketujuh. Muhammad Ghazan (1295-1304 M.) adalah pemeluk agama Islam Dengan hadirnya Ghazana Khan sebagai penguasa Dinasti Ilkhan, Islam sedikit demi sedikit mulai meraih kemenangan yang sangat besar terhadap agama Syamanism. Ketika kepemimpinan telah mulai melemah muncul sosok Gazana Khan dari keturunan Mongol yang pada saat itu telah tertarik memeluk dan mempelajari Islam. Kebijakan Mahmud Ghazan terhadap mayarakat Islam di daerah Persia telah meraih kemenangan yang sangat besar terhadap Agama Syamanisme bangsa Mongol. ${ }^{32}$

Kehadiran Gazana Khan di tengah-tengah Masyarakat Muslim yang mengalami penderitaan dari bangsa Mongol merupakan kemenangan besar bagai Ummat Islam. Ghazana Khan menetapkan pemerintahannya dengan menjadikan Islam sebagai agama resmi kerajaannya, walupun pada mulanya Bergama Budha akan tetapi Gazana Khan mempelajari agama-agama sebelum memeluk agama Islam. Ketertarikan Gazana Khan masuk Islam dikarenakan pengaruh seorang menterinya yaitu Shekh Sadr al-Din seorang ulama yang terkemuka, dan Nawruz seorang gubenurnya untuk beberapa propinsi Syria.

Dalam catatan sejarah Sultan Ghazan merupakan raja Mongol pertama yang mencetak uang dinar dengan inskripsi Islam. Syariat Islam kemudian kembali ditegakkan dan undangundang kerajaan diganti dengan undang-undang baru yang berasaskan Islam. Pada bulan November 1297 amir-amir Mongol mulai memakai jubah dan surban, dan membuang pakaian adat nenek moyangnya. Walaupun perubahan itu menyebabkan banyak orang Mongol yang masih beragama Budha tidak puas, dan terus menerus menyebarkan intrikintrik dan meletuskan sejumlah pemberontakan, namun pemerintahan Ghazan relatif aman. Reformasi lain yang dia lakukan ialah pengurangan pajak dan penyusutan jumlah pelacuran dan lokasinya diseluruh negeri. ${ }^{33}$

Sultan Ghazan wafat pada tanggal 17 Mei 1304 dalam usia 32 tahun disebabkan konspirasi politik yang bertujuan mengangkat Alafrank, putra saudara sepupunya Gaykhatu, Kematiannya ditangisi di seluruh Persia. Dia bukan hanya seorang negarawan muda yang bijak dan taat beribadah, tetapi juga pelindung ilmu dan sastra. Dia menyukai seni, khususnya arsitektur, karejinan dan ilmu alam. Dia mempelajari astronomi, kimia, mineralogy,

\footnotetext{
${ }^{31}$ http://referensiagama.blogspot.com/2011/01/dinasti-ilkhaniyah.html

${ }^{32}$ C.E. Bosworth, ter. Ilyas Hasan, Dinasti-Dinasti Islam, (Bandung, Mizan, 1993), h. 176.

${ }^{33}$ C.E. Bosworth yang diterjemahkan oleh, Ilyas Hasan, Dinasti-Dinasti Islam . h. 175
} 
metalurgi, dan botani. Dia menguasai bahasa Persia, Arab, Cina Mandarin, Tibet, Hindi dan Latin. $^{34}$

Uljaytu Khudabanda (1304-1316), meneruskan kebijakannya Mahmud Ghazan, Figur Muhammad Khudabanda Uljaetu di samping sebagai seorang yang taat memegang agama Islam, Ia adalah seorang penganut dan pembela madzhab Syiah. Ia mengendalikan pemerintahan Dinasti Ilkhan selama kurang lebih 14 tahun, sampai kemudian digantikan oleh Abu Said (1317-1335 M.). Dinasti Ilkhan mengalami kemunduran pasca pemerintahan Abu Said. Perlu diketahui bersama pada masa ini Dinasti Ilkhan diperintah Raja Arpha, Musa, Muhammad, Jahan Timur, Sati Bek dan Sulaeman. Mereka semua adalah figur raja-raja yang lemah, karena di masa ketujuh raja ini di wilayah kerajaan Dinasti Ilkhan banyak terjadi perpecahan dan pertikaian, sehingga wilayah kekuasaannya digantikan oleh dinasti-dinasti lokal seperti Dinasti Jalayiriyah, Muzhaffariyyah dan Sarbadariyyah di Khurasan. ${ }^{35}$

Wilayah Ilkhaniyah yang berada di Irak, Kurdistan dan Azerbeijan diwarisi oleh Dinasti Jalayiriyah, tetapi masih memusatkan kekuasaan di Baghdad. Di masa Uways, pengganti Hasan Agung, ia dapat menaklukkan Azerbeijan, tetapi mendapat perlawanan dari Dinasti Muzaffariyah dan penguasa Horde keemasan. Tetapi mereka dapat ditaklukkan oleh Qara Qoyunlu (Domba Hitam) yaitu orang-orang Turkmen yang lari ke Timur akibat invasi Mongol. Kedudukan Dinasti-Dinasti ini dapat bertahan sampai datangnya Timur Lenk yang mempersatukan mereka dengan membentuk Dinasti Timuriyah yang berpusat di Samarkand. ${ }^{36}$

Selanjutnya, sampai dengan dengan dekade keempat dari abad XIV, tepatnya di tahun 1343 M kekuasaan dari Dinasti Ilkhan sudah tidak ada dan sisa-sisa dari wilayah kekuasaannnya di masa kemudian diambil alih dan dipersatukan oleh Timur Lenk sebagai satu kesatuan integritas di bawah panji-panji kekuasaannya.

\section{PENUTUP}

Dari apa yang telah dipaparkan pembahasan mengenai bangsa Mongol mendirikan kerajaan dinasti Ilkhan berbasis Islam pasca kehancuran Baghdad 1258-1347 M.

Keberhasilan ekspansi yang dilakukan oleh Hulagu Khan terutama kehancuran Baghdad tahun 1258 M. telah mendirikan suatu kerajaan Mongol dengan gelar Ilkhan. Dinasti Ilkhan adalah sebuah dinasti yang dibangun oleh orang-orang Mongol, ketika mereka berhasil menginvasi dan menguasai Baghdad sebagai pusat kekuasaan dari Khilafah Abbasiyah. Dinasti Ilkhan berdiri pada tahun 1258, Dinasti Ilkhan yang didirikan oleh Hulagu Khan memliki kekuasaan meliputi dari lembah sungai Amu Daria sampai Syam dan dari Kawkasus sampai Hidukush. dalam sejarah Islam membawa fase baru kejayaan Islam pasca kehancuran Baghdad.

Baghdad dan daerah-daerah yang ditaklukkan Hulagu Khan selanjutnya diperintah oleh Dinasti Ilkhan, Ummat Islam dengan demikian dipimpin oleh Hulagu Khan seorang raja yang beragama Syamanisme. Kondisi kehidupan keberagaman pada masa Hulagu Khan sangatlah toleran, akan tetapi kemajuan Islam di antara bangsa Mongol sangatlah lamban

\footnotetext{
${ }^{34}$ C.E. Bosworth yang diterjemahkan oleh, Ilyas Hasan, Dinasti-Dinasti Islam, h. 176-177

${ }^{35}$ C.E. Bosworth, ter. Ilyas Hasan, Dinasti-Dinasti Islam, h. 175.

${ }^{36}$ Philip K. hitty, History Of The Arbas, (Cet. I; London: The Macmillan Press, 1974), h. 207-208.
} 
dibanding agama Kristen dan Budha. Umat Islam yang ada di kawasan Baghdad diperintah dan dikuasai oleh penguasa-penguasa Dinasti Ilkhan yang non-Muslim. pada periode ini tidak ada sebuah perkembangan yang berarti bagi masyarakat Muslim terutama yang menyangkut perkembangan Islam dan peradabannnya, karena penguasa-penguasa dari dinasti Ilkhan pada periode ini adalah orang-orang yang tidak memiliki perhatian terhadap Islam. Terutama pada masa pemerintahan Gaykhatu dan Baydu yang waktunya cukup singkat tidak melakukan perubahan dan perbaikan apapun hanya meneruskan bentuk pemerintahan sebelumnya. Pada masa kepemimpinan Gaykhatu dan Baydu termasuk pemimpi Mongol yang lemah dalam pemerintahanya.

Gazana Khan adalah penguasa Dinasti Ilkhan yang ke tuju walaupun pada awalnya memeluk agama Budha namun atas bujukan dari penasehatnya ialah Amir Nawruz berjuang merebut tahta kerajaan dari saingan utamanya, panglima jendral Nawruz membantu perjuanganya melawna saudaranya Baydu. Atas keberhasilanya tersebut Gazana Khan telah memantapkan dirinya untuk belajar agama Islam. Shekh Sadr al-Din yang merupakan salah seorang ulama Syi'ah Gazana Khan bertanya sejelas-jelasnya dan sedetail-detailnya mengenai ajaran agama Islam, Gazana Khan memantapkan dirinya dan mengucapkan dua kalimah syahadat di hadapan Syekh Sadruddin Ibrahim, putra tabib terkemuka al-Hamawi.

Setelah para pemimpinnya masuk Islam masyarakat dari kalangan Bangsa Mongol dapat menerima dan masuk agama Islam, dikarenakan mereka berasimilasi dan bergaul dengan masyarakat muslim dalam jangka waktu panjang. Sehingga adanya keinginan tertrik memeluk Islam. Para penguasa dari Dinasti Ilkhan sejak masa kekuasaan Gazana Khan mulai memperhatikan Islam dan kepentingan masyarakat Muslim, serta memposisikan dirinya melalui pembaruan dengan lingkungan masyaraka disekelilingnya, masyarakat Muslim terlebih muslim di Iran telah mendapatkan kemerdekaannya kembali.

\section{DAFTAR PUSTAKA}

Anmol Publication pvt. Ltd, Internasional Encyclopaedia of Islamic Dynasties, Cet.I; Delhi: Mehra Offset Press, 2000

Black, Antoni. pemikiran politik Islam, Cet. I; Jakarta: PT Serambi Ilmu Semesta, 2006

C.E, Bosworth,.diterjemahkan oleh, Ilyas Hasan, Dinasti-Dinasti Islam, Cet. II; Bandung; Mizan, 1993.

Departemen Agama, Al-Quran dan terjemahnya (Jakarta: Darus Sunnah, Ed. 2002), h. 446.

HulaguKhan, Wikipedia.http://id.wikipedia.org/w/index.php?title=Hulagu_Khan\&oldid (13 Agustus 2012).

http://referensiagama.blogspot.com/2011/01/dinasti-ilkhaniyah.html

I ra M. Mapidus, Sejarah Sosial Ummat Islam, ter. Ghufron A. mas'adi, Cet. II; Jakarta: PT Raja Grafindo Persada, 2000.

Ibrahim Hassan, Hasan. Sejarah Dan Kebudayaan Islam, Cet. I; Yokyakarta, Kota Kembang, 1989

Ibrahim Hasan, Hasan. Tarik Al-Islam, Jilid IV, Kairo, Maktabah An-Nahdah Al-Misriyah, 1979

Joesoef Sou'yb, Sejarah Daulat Abbasiyah, Jilid III (Cet. I; Jakarta: Bulan Bintang, 1978), h. 324. 
Karim, Abdul. Islam di Asia Tengah; Sejarah Dinasti Mongol - Islam, Yogyakart: Bagaskara, 2006

Morgan, d avid . The Mongols, Cambridge : Black Well, 1990,

Mahdu Al-qadhi , Muhammad, 10 Pahlawan Penyebar Islam, Cet. I; Yokyakarta: Mitra pustaka,2003

Muhammad, Najamuddin. Jengis Khan:Sang Pengembala yang Menaklukan Dunia, Cet. I; Jokjakarta: Buku Biru, 2010.

Munir, Samsul. Sejarah Peradaban Islam, Cet.II; Jakarta : Amzan, 2010.

Syalabi, Ahmad. Mausu'ah al-Tarikh al-Islami wa al-Hadharah al-Islamiyah, Cet. VII; Kairo: Maktabah al-Nahdhah al-Mishriyah, 1979.

Tim Riset dan Studi Islam Mesir: Ensiklopedi Sejarah Islam Imperium Mongol Muslim, Negara Utsmani, Muslim Asia Tenggara, Muslim Afrika, Cet. I; Jakarta: Al-Kautsar, 2013.

Philip K. hitty, History Of The Arbas, Cet. I; London: The Macmillan Press, 1974.

Yunahar Ilyas, Kuliah Akhlak, Cet. X; Yokyakarta: pustaka pelajar offset, 2009. 